\title{
The Subject-Specific Pedagogy (SSP) of STM-Biblical integrated based Geography to improve the Christian Worldview of Eleventh Graders in SMA Kristen Kalam Kudus, Sukoharjo
}

\author{
$1^{\text {st }}$ Sudrajat Arif Krisanjaya \\ SebelasMaret University, \\ Surakarta, Indonesia.
}

\author{
$2^{\text {nd }}$ Sarwono \\ SebelasMaret University, \\ Surakarta, Indonesia.
}

\author{
$3^{\text {rd }}$ Chatarina Muryani \\ SebelasMaret University, \\ Surakarta, Indonesia.
}

\begin{abstract}
This study aims to know the development of SSP of STM-Biblical integrated based Geography, and to know the feasibility of SSP of STM-Biblical integrated based Geography to improve the Christian Worldview of Eleventh Graders in SMA Kristen Kalam Kudus, Sukoharjo in the academic year of 2017/2018. This type of study was Research and Development ( $R$ \& D). This stage used 4D development model. In this study, the writer only focused on 3-D stage (Define, Design, Develop). This research design used pre-testpost-test method design. The subjects of the study were the eleventh graders of IPS in SMA Kristen Kalam Kudus Sukoharjo. The data collection techniques used were methods of observation, interviews, tests, questionnaires and documentation while the analysis technique used t-test. The characteristic of this SSP is the integration of learning stages based on STM and the insertion of Biblical values which aims to improve Christian Worldview of eleventh graders of SMA Kalam Kudus Sukoharjo Senior High School students. The validation result from the expert team shows the average syllabus and lesson plan assessment of $87.6 \%$ so that it belonged to very reasonable criteria, the average module rating was $86.8 \%$ and belonged to very reasonable criteria, the average Students worksheet rating was $91 \%$ and belonged to very feasible criteria. The response of the students' test responses showed a positive response with percentage $85 \%$ and was belonged to very reasonable criteria.
\end{abstract}

Keywords- Development of SSP, STM, Biblical Integration, Christian Worldview

\section{INTRODUCTION}

According to Zuhdan K.P (2011: 4), Subject Specific Pedagogy (SSP) is the packaging of the field of study into a comprehensive learning tool covering standardscompetency, materials, strategies, methods, media, and evaluation (assessment instrument of learning outcomes). The SPP includes: syllabus, lesson plan, teaching material (student book), student worksheet and items [1].

According to John W. Taylor (General Conference Session, San Antonio, 2015) the integration model that occurs in Christian school learning is still in the form of a disjunctive phase which means that the reduction of Christian worldview learning is done in the form of "slot" lesson time [2]. Khoe Yao Tung (2015: 178) revealed that "In Indonesia, there is no publication of biblicalbased textbooks in accordance with the national curriculum." This is a great home work to be thought of and used by Indonesian Christian education figures. Understanding this reality, the author tries to do research and development in the preparation of teaching-based instructional module of teaching. The author hopes that this module can help in the midst of the diverse quality of Christian teachers [3].

The task of Christian education is to guide students to see life from Allah's perspective and to steer student growth to Allah's purpose for humanity - a divine character and action (Howard, 2008) [4]. A great hope of the author that with teaching materials in the form of this biblical-based integration module, it will develop textbooks and teaching materials of biblically integrated subjects with aim of forming Christian worldviewof students. Worldview is a belief system of the accumulated results of experience, thought, and culture that becomes an insight into one's thinking (Tung, 2015: 51). Worldview is a paradigm, a reasoning ground, an accumulation of ideas, assumptions of beliefs of life and all that students have gained during their life up to now [3].

Learning through the STM learning model can develop between science and technology and its benefits in society (Anna Poedjiadi, 2007: 123) [5]. Students who have science and technology literacy will be able to solve problems using science concepts derived from education in line with their grade, recognize existing technology products and its impacts, enable to use technology products and maintaining it, creative in making simplified technology and capable to take decisions based on value [6]. 


\section{METHODS}

This research is a kind of research development (Research and Development) or called by $R \& D$ research. The researcher used R \& D 4-D model which designed by Thiagarajan (in Trianto, 2010) [7]. The study was conducted at SMA Kristen Kalam Kudus Sukoharjo in the year of 2018. The population in this study is the students of XI IPS class in the academic year of 2017/2018 that is IPS 1-3. Sampling used probability sampling that is cluster random sampling, premises homogeneity test so that two classes is chosen to be sample that are XI IPS 1 class and XI IPS 2 class (control and experiment class).

The Development of Specific Pedagogical Subject (SSP) based Inquiry in this study adopted R \& D 4-D (define, design, develop, and disseminate) model. It was designed by Thiagarajan which focused on the research stages of $\mathrm{R} \& \mathrm{D} 4 \mathrm{D}$ implementations as follow:

\section{Stage I: Defining}

In this research and development, the researcher observed the obstacle found at Christian Senior High School (SMA) Kalam Kudus, Sukoharjo which applied curriculum 2013. The observation conducted by the researcher went as follow:

1. Front End Analysis

Front End Analysis was conducted to determine the root of the problem required to develop the learning devicebased on the STM which was integrated with Biblical principles.

2. Students' Character Analysis

Christian Worldview. The activity of student analysis was the study of students' characteristic which were suitable with the plan and development of learning materials. The students' characteristics could be obtained after they filled up the instrument ofChristian Worldview.

3. Analysis of Materials and Teaching Materials

Analysis of learning materials aimed to know the difficulty of learning materials for students. Meanwhile analysis of teaching materials was used to know the characteristics from teaching materials at school. This analysis was reflected from the previous academic year.

4. Learning Goal Specification

The last stage in identification was the stage to formulate the aim. Based on the aforementioned analysis, it needed a supplement to anticipate such condition by developing Pedagogical-specified subject (SSP) according to curriculum 2013 on subject Geography dealing with topic of life environment for eleventh grade(XI) of social science students.

Stage II: Design
The researcher's effort to overcome the problem at school was by designing teaching materials. On this stage, the researcher designed SSP based on STM integrated with Biblical principles. SSP component included Syllabus, lesson plan, students' books, students' worksheet, and the evaluation device of SSP which was produced on this stage and was called as Draft I.

Stage III: Development

SSP products which had been designed and developed into draft I, then was analyzed by SSP product validation, SSP product revision, , preliminary field test, research object test, evaluation and completion

1. Validating product ofSSP

Product validating by experts aimed to evaluate the design feasibility and product development before it was applied in the field.

2. Design revision of SSP Device.

After data were validated, the drawbacks would appear. Such drawbacks would then be fixed so that the final result of SSP Product was appropriate to test.

3. Implementation Stage

Products which had been validated, then was tested to the students to know the response of SSP products. Test was carried out in two stages as follow:

\section{a. Preliminary Field Test}

Preliminary Field Test covered eight students and a teacher of geography. This was to revise the first stage on the SSP product based on the STM integrated with Biblical principles made.

\section{b. Operational Field Test}

It constituted a field test which covers a class of XI social science. This was to know the effectiveness of product made so that the product of SSP was appropriate to use.

Stage IV: Evaluation Stage

Evaluation stage was carried out after the previous stages which then result in the final SSP product based on the STM integrated with Biblical principles.

The data validation towards feasibility of the product could be analyzed through questionnaire used in the form of Likert Scale (Sugiyono: 2011) [8]. Here were the formulas used:

$$
\begin{aligned}
& \qquad P=\frac{f}{N} \times 100 \% \\
& \text { Note : }=\text { Score percentage } \\
& \mathrm{P}=\text { Sum of score obtained from the validator } \\
& \mathrm{f}=\text { Sum of maximumscore }
\end{aligned}
$$

Validator will answer the question by giving score based on validation rubric (highest score $=5$ and 
lowest score=1). Validation criteria are determined based on the following criteria (Sudjana, 2010) [9]:

\begin{tabular}{cc} 
TABLE I.PERCENTAGE AND FEASIBILITY OF \\
SSP PRODUCTS \\
\hline Percentage & Description \\
\hline $0 \%<\mathrm{P} \leq 25 \%$ & Very Unfeasible \\
$25 \%<\mathrm{P} \leq 50 \%$ & Unfeasible \\
$50 \%<\mathrm{P} \leq 75 \%$ & Feasible \\
$75 \%<\mathrm{P} \leq 100 \%$ & Very Feasible \\
\hline
\end{tabular}

Christian Worldviewis determined based on the following criteria (Pujiyanto, 2017) [10]:

TABLE II. PERCENTAGE AND CHRISTIAN WORLDVIEWCRITERIA

\begin{tabular}{|c|c|}
\hline Percentage & Description \\
\hline $0 \%<\mathrm{P} \leq 25 \%$ & The Socialist Worldview \\
\hline $25 \%<\mathrm{P} \leq 50 \%$ & The Humanist Worldview \\
\hline $50 \%<\mathrm{P} \leq 75 \%$ & Moderate \\
\hline $75 \%<\mathrm{P} \leq 100 \%$ & Worldview \\
\hline & Strong Biblical Worldview \\
\hline
\end{tabular}

\section{RESULTS AND DISCUSSION}

\section{Result of the Development and Feasibility of the Product}

Subject Specific Pedagogy (SSP), product of the research, consists of syllabi component, lesson plan, students' worksheet and evaluation instrument designed based on the syntax of Sains Teknologi Masyarakat (STM)learning model which is integrated with Bible (Christian). Moreover, the design of the product is also adapted to the 2013 curriculum that includes cognitive, affective, and psychomotor competencies.

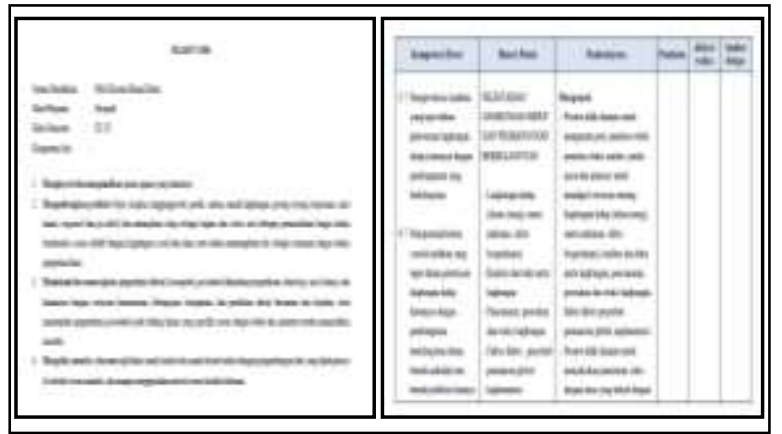

Picture 1.The example of syllabus

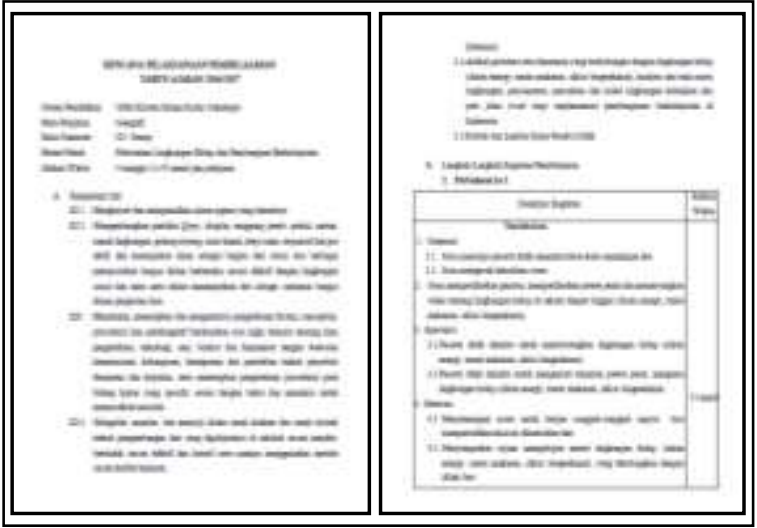

Picture 2.The example of lesson plan

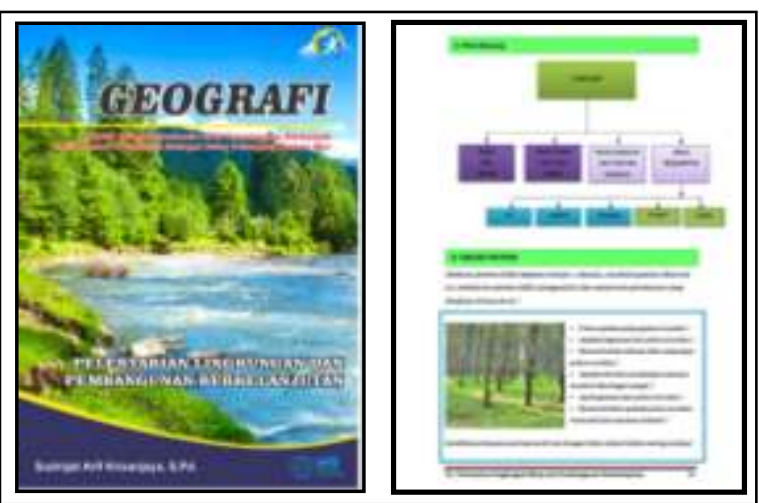

Picture 3. The example of module

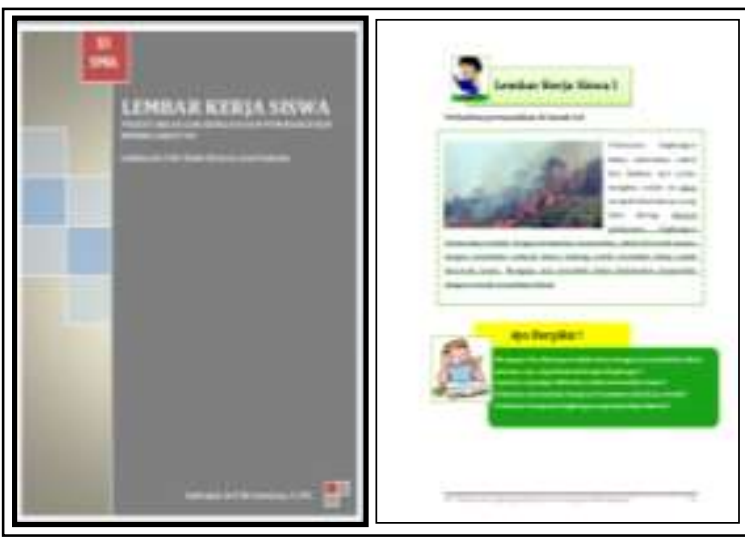

Picture 4.The example of students' worksheetPicture

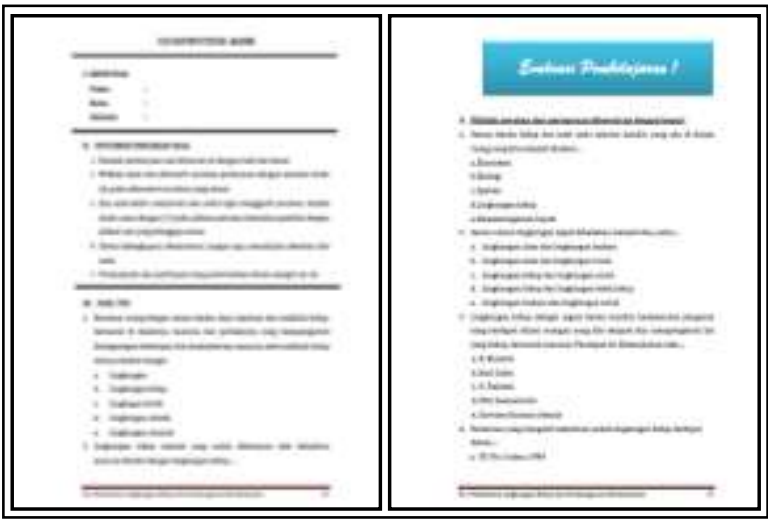




\section{The example of Evaluation Instrument}

Expert appraisal is a technique used to validate or evaluate the feasibility of product design; evaluation process will be done by the expert in that field. The following is the result of product validation by some experts such as the experts of subject matter, the experts of media and geography teacher.

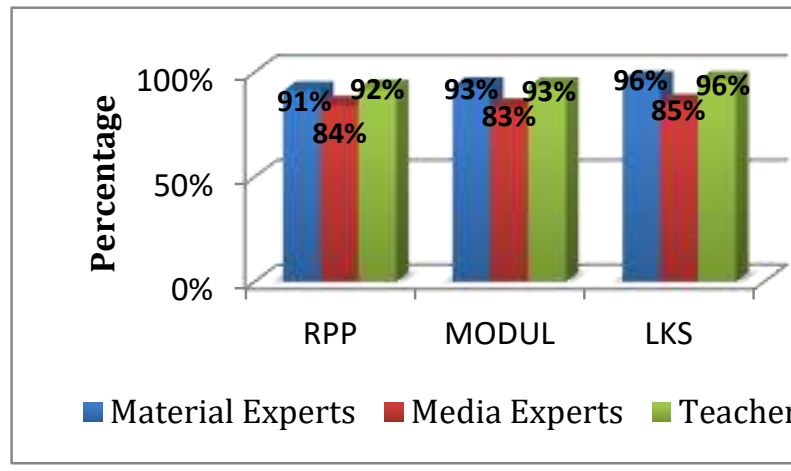

Picture 6. Product validation graph

Here is the average of product validation result which is gotten from some experts such as the experts of subject matter, the experts of media and geography teacher.

TABLE III. THEAVERAGE OF PRODUCT VALIDATION RESULT

\begin{tabular}{cccc}
\hline & \multicolumn{3}{c}{ Product } \\
\cline { 2 - 4 } & Lesson Plan & Module & $\begin{array}{c}\text { Students' } \\
\text { Worksheet }\end{array}$ \\
\hline \hline $\begin{array}{c}\text { Average } \\
\text { (Percentage) }\end{array}$ & $89 \%$ & $90 \%$ & $92 \%$ \\
\hline
\end{tabular}

Developmental testing is an experimental activity of product design on limited targets / scales. In this case, product design were tested to geography teacher and nine students and assessedusing limited trial feasibility instrument. The test results are used to improve the product.

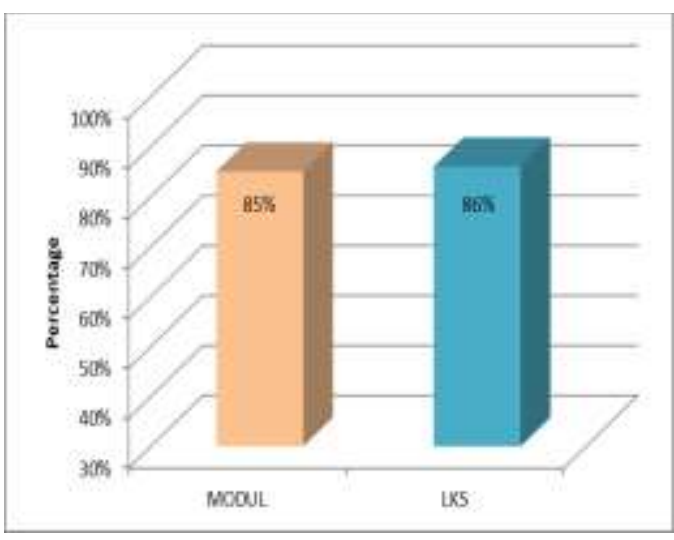

Picture 7.The graph of limited trial result by the students

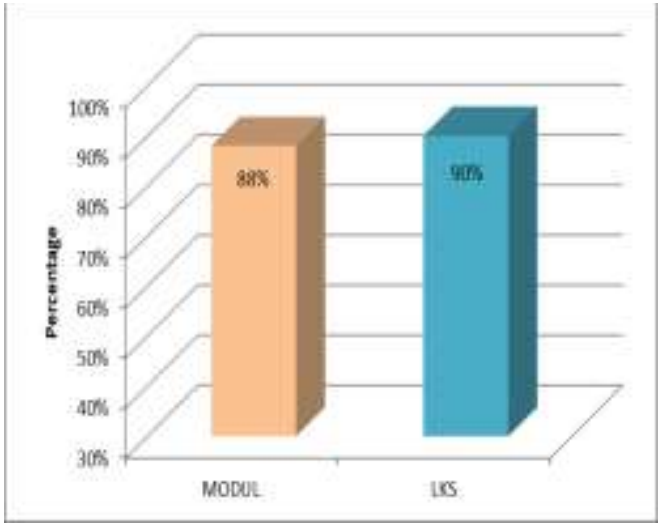

Picture 8.The graph of limited trial result by the teacher

\section{Discussion}

The results obtained from the validation test as a whole are eligible criteria that are highly feasible to use or apply in learning. The result of validation test for lesson plan of substance aspect was $91 \%$ with very feasible criteria, media aspect was $84 \%$ with very feasible criteria, and assessment of geography teacher was $92 \%$ with very feasible criteria as well. The validation test for the Alkitabiah Integrated STM-based module of the substance aspect was $93 \%$ with very reasonable criteria, the media aspect was $83 \%$ with very reasonable criteria, and the assessment of the geography teacher was $93 \%$ with very reasonable criteria as well.The validation test results for the Alkitabiah intregated STM-based student worksheet of the substance aspect was $96 \%$ with very reasonable criteria, the media aspect of $85 \%$ with very reasonable criteria and the Alkitabiah intregated STM-based student worksheet assessment of geography teachers was $96 \%$ with very reasonable criteria. Alkitabiah intregated STM-based SSP was eligible from various aspects of assessment by expert judgments to apply in either limited trials or field trials.

Limited trials were followed by nine students and one teacher to assess modules and paper worksheet. Module test results from students obtained $85 \%$ with very feasible criteria and Paper worksheet obtained $86 \%$ with very feasiblecriteria. Module trials by teachers obtained $88 \%$ with very feasible criteria and paper worksheet obtained $90 \%$ with very feasible criteria which were given by students and teachers in the evaluation of modules and LKS.Modules and Student worksheet which have been assessed by student and teacher respondents from a limited trial were eligible for further use in field trials.

\section{CONCLUSION}

Based on the results of the research, it can be concluded that:

1. The characteristics of Alkitabiah Integrated STM-based SSP on Environmental preservation and sustainable development material exist the insertion of Christian Worldview dimension in the product that consists of stage 1: Introduction 
of Initiation / Invitation / Apperception (issue raising or geosphere problem),stage 2: The establishment or development of concepts,stage 3: Application of life concepts (problem solving or problem analysis using scientific theories and Christian values),stage 4: Consolidation of the concept, stage 5: Assessment.

2. Development of Subject Specific Pedagogy of Biblically integrated STM-based which includes lesson plans, modules, student worksheets, and assessment instruments with 4D Thiagarajan has been through the validation stage by experts and limited trials have been declared eligible for use in class XI Social science of Christian Kalam Kudus High School Sukoharjo on the material of environmental conservation and sustainable development.

\section{ACKNOWLEDGMENT}

I am really grateful to the principal of SMA Kristen Kalam Kudus Sukoharjo who gave me permission to do the research, and I am also grateful to all teachers and students who have been involved in this research.

\section{REFERENCES}

[1] Zuhdan K.P. (2011). Pengembangan perangkat pembelajaran sains terpadu untuk meningkatkan kognitif, keterampilan proses, kreativitas serta menerapkan konsep ilmiah peserta didik SMP.Universitas Negeri Yogyakarta: Yogyakarta

[2] Taylor, John. W., (2015). "General Conference Session". San Antino.

[3] Tung K. Y., (2015). Menuju Sekolah Kristen Impian Masa Kini. Yogyakarta: ANDI.

[4] Howard, Donald R., (2008).Wisdom: A Philosophy of Christian Education. Louisville: Accelerated Christian Education.

[5] Poedjiadi, Anna. (2007). SainsTeknologiMasyarakat. Bandung: RemajaRosdakarya Offset.

[6] Krisanjaya S. A., (2015).Penerapan Model Pembelajaran Sains Teknologi Masyarakat (Stm) untuk Meningkatkan Hasil Belajar Geografi Dan Sikap Peduli Lingkungan.Skripsi. Universitas Sebelas Maret: Surakarta.

[7] Trianto. (2010). Model Pembelajaran Terpadu. Jakarta: Bumi Aksara.

[8] Sugiyono. (2011) MetodePenelitianKuantitaifdanKualitatif. Bandung: Alfabeta.

[9] Sudjana, Nana. (2010). PenilaianHasil Proses BelajarMengajar. Bandung: RemajaRosdakarya.

[10] Pujiyanto H., (2017). Pengembangan Bahan Ajar Guru Berbentuk Modul Berbasis Bible-Based Integration (BBI) untuk Membentuk Christian Worldview pada Siswa SMP Kristen di Surakarta. Tesis. Universitas Sebelas Maret: Surakarta. 